\section{Studies on Seasonal and Spatial Distribution of Zooplankton Communities and Their Diversity Indices at Chashma Lake, Pakistan}

\author{
Huma Ayub ${ }^{1}$, Iftikhar Ahmad ${ }^{2}$, Syed Lal Shah ${ }^{3, *}$, Muhammad Zafarullah Bhatti ${ }^{4}$, \\ Nuzhat Shafi ${ }^{5}$ and Mazhar Qayyum ${ }^{1}$ \\ ${ }^{1}$ Department of Zoology, Pir Mehar Ali Shah Arid Agriculture University, Rawalpindi \\ ${ }^{2}$ Fish Hatchery, Rawal Town, Islamabad \\ ${ }^{3}$ Pakistan Science Foundation, Islamabad \\ ${ }^{4}$ Fish Biodiversity Hatchery, Chashma \\ ${ }^{5}$ Department of Zoology, The University of Azad Jammu and Kashmir, Muzaffarabad
}

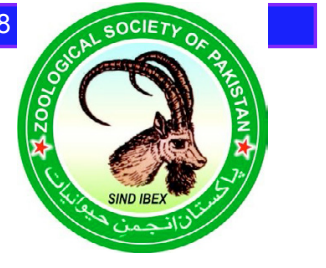

CrossMark

Article Information

Received 21 February 2018

Revised 07 April 2018

Accepted 11 April 2018

Available online 21 May 2018

Authors' Contribution

MQ planned the research project.

HA Collected samples, performed

laboratory work and wrote the article.

IA and MZB helped in sampling.

SLS provided laboratory facilities at

Pakistan Museum of Natural History,

Islamabad and identified zooplankton

species. NS Proofread the manuscript

and helped in data analysis.

Key words

Zeoplankton, Chashma Lake,

Zooplankton, Chashma Lake,
Diversity, Seasonal, Spatial. followed by rotifers and cladocerans for entire study period. The spatial distribution of zooplankton was not found prominent as compared to their seasonal distribution. However, rotifers showed spatial difference among sampling stations (ANOVA, $p$-value $<0.05$ ). The present study provides a first detailed spatial and seasonal distribution of zooplankton in Chashma Lake, which may be a road map for further studies on zooplankton diversity in other freshwater lakes in the region.

\section{INTRODUCTION}

Z ooplankton play an important role in aquatic environment. They actively participate in food chain and are responsible for nutrients recycling and energy transfer from producers to secondary and tertiary consumers (Datta, 2001; Park and Shin, 2007). They are also used as a direct prey for fish and large invertebrates. Influence of various physicochemical parameters, geographical features and complex diversity of zooplankton result in difficulty in zooplankton examination. They are considered as an important component of aquaculture and are also used as indicators of water quality, pollution level and status of eutrophication in freshwater bodies (Saler, 2009; Thor et al., 2005; Hwang et al., 2009). In Pakistan, some studies have been carried out on various aspects of zooplankton (Mahar et al., 2000, 2008; Baloch, 2000; Baloch and Soomro, 2004; Baloch et al., 2004,

\footnotetext{
* Corresponding author: drsyed_1@yahoo.com 0030-9923/2018/0004-1293 \$ 9.00/0

Copyright 2018 Zoological Society of Pakistan
}

2005; Kazmi, 2004; Shelly et al., 2011; Naz et al., 2012; Shah et al., 2013; Maqbool et al., 2014; Saddozai et al., 2015). However, no study on the zooplankton communities of Chashma Lake has so far been conducted.

The present study was conducted to determine the zooplankton species composition and distribution in Chashma Lake, which may be helpful in aquaculture management especially in fish hatchery sector, as the zooplankton are the main source of food for aquatic animals particularly for fish fry in freshwater ecosystem.

\section{MATERIALS AND METHODS}

\section{Study site}

Chashma Lake is a manmade lake and is situated on Indus River at $32^{\circ} 25^{\prime} \mathrm{N}, 71^{\circ} 22^{\prime} \mathrm{E}$. This is a shallow lake and a wetland of international importance and is also a RAMSAR Site (Akbar et al., 2009). In order to obtain a comparative report of zooplankton distribution from the different sites, three stations S1, S2 and S3 were selected for study and marked by GPS. 
Sampling

Zooplankton samples were collected on a monthly basis from June 2014 to May 2015. Five liters of water was filtered through a zooplankton net (mesh size $80 \mu \mathrm{m}$ ) from 1 to 2 feet depth at each site for the zooplankton population and preserved in $5 \%$ formalin and shifted to Pakistan Museum of Natural History, Islamabad, Pakistan. In laboratory, zooplankton samples were analyzed and counted under light microscope (BH2 OLYMPUS, Japan with rotator eyepiece 10x) with the help of counting chamber. Various magnifications of 20x, 30x, 40x and $100 \mathrm{x}$ were also used for examination of specimens. Identification of zooplankton was made with the help of different taxonomic keys (Ward and Whipple, 1959; Pennak, 1978; Yunfang, 1995; Mizuno and Takahashi, 1991; Battish, 1992).

Table I.- List of zooplankton species observed at Chashma Lake during June 2014-May 2015.

\begin{tabular}{ll}
\hline S Species name & S Species name \\
No. & Ro. \\
\hline Cladocerans & Rotifers \\
1 Bosmina longirostris & 22 Skistodiaptomus pallidus \\
2 Alona guttata & 23 Hexarthra mira \\
3 Alona recticulata & 24 Filinia longiseta \\
4 Chydorus poppie & 25 Asplanchna brightwelli \\
5 Ceriodaphnia cornuta & 26 Asplanchna priodonta \\
6 Ceriodaphnia reticulate & 27 Brachionus angularis \\
7 Daphnia lumholtzi & 28 Brachionus clyciflorus \\
8 Scapholeberis kingi & 29 Brachionus havanaensis \\
9 Simocephalus exspinosus & 30 Brachionus patulus \\
10 Macrothrix rosea & 31 Brachionus quadridentatus \\
Copepods & 32 Keratella cochlearis \\
11 Diacyclops bicuspidatus & 33 Keratella tropica \\
12 Eucyclops agilis & 34 Keratella valga \\
13 Eucyclops macrurus & 35 Notholca foliacea \\
14 Ectocyclops phaleratus & 36 Notholca squamula \\
15 Macrocyclops albidus & 37 Platyias quadricornis \\
16 Macrocyclops fuscus & 38 Euchlanis triquetra \\
17 Mesocyclop edax & 39 Lecane arcula \\
18 Mesocyclop leukarti & 40 Lepadella species \\
19 Microcyclops varicans & 41 Notommata tripus \\
20 Diaptomus species & 42 Polyarthra species \\
21 Onychodiaptomus mohammad \\
\hline
\end{tabular}

\section{Statistical analysis}

The data for spatial difference was analyzed through Box-plot by using R Studio (3.2.5 version) and ANOVA test to see the difference between sites, whereas, the relative occurrence was measured to know the abundance of zooplankton. Diversity indices were measured by using R Statistical VEGAN package (3.4.0 version). The indices used for the measurement of diversity and richness were; a) Shannon Index, b) Evenness or Pielou Index, c) Simpson Index, and d) Margalef Index.

\section{RESULTS AND DISCUSSION}

The present study reveals that a total 42 species of zooplankton were found in Chashma Lake belonging to three taxa viz.; rotifers, cladocerans and copepods. Of these, 20 species belong to rotifers, 12 species to copepods and 10 species to cladocerans (Table I). On the basis of percent occurrence throughout the year, the copepods were found more abundant $(47.93 \%)$ followed by rotifers $(33.67 \%)$ and cladocerans $(18.38 \%)$. The physical characteristics of three sampling sites in Chashma Lake are given in Table II.

Table II.- Physical characteristics of Chashma Lake.

\begin{tabular}{lccc}
\hline Parameters & \multicolumn{3}{c}{ Name of station } \\
\cline { 2 - 4 } & $\begin{array}{c}\text { S1 } \\
\text { Main Basin }\end{array}$ & $\begin{array}{c}\text { S2 } \\
\text { Hajji Basin }\end{array}$ & $\begin{array}{c}\text { S3 } \\
\text { Dera Basin }\end{array}$ \\
\hline Latitude & $\mathrm{N} 32^{\circ} 26.110$ & $\mathrm{~N} 32^{\circ} 26.229$ & $\mathrm{~N} 32^{\circ} 27.141$ \\
Longitude & $\mathrm{E} 071^{\circ} 25.571$ & $\mathrm{E} 071^{\circ} 23.664$ & $\mathrm{E} 071^{\circ} 20.919$ \\
Average depth (m) & 4.14 & 4.29 & 5.15 \\
Flow velocity & 44.41 & 51.66 & 108.91 \\
$(\mathrm{~cm} / 2$ min) & & & \\
Color & Dark green & Dark green & Grey green \\
\hline
\end{tabular}

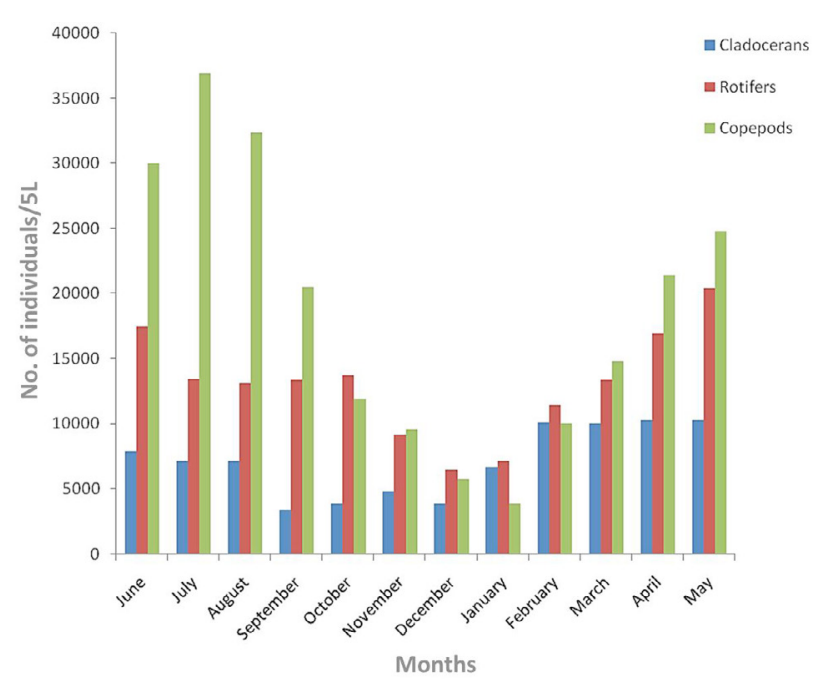

Fig. 1. Average monthly abundance of major zooplankton groups in Chashma Lake between June 2014 and May 2015. 
Regarding seasonal variation in zooplankton species, it was found that the copepods were dominant in summer (March to September), followed by rotifers. Whereas, in winter rotifers were prominent in occurrence as compared to copepods. The cladocerans were dominant from early spring to summer and less in winter (Fig. 1).

Table III.- Values of diversity indices for different sites and months at Chashma Lake during June 2014-May 2015.

\begin{tabular}{|c|c|c|c|c|c|}
\hline $\begin{array}{l}\text { Months and } \\
\text { sites }\end{array}$ & Margalef & $\mathbf{A}$ & B & $\mathrm{C}$ & D \\
\hline June.S1 & 3.61 & 3.59 & 0.97 & 33.69 & 0.97 \\
\hline June.S2 & 3.71 & 3.63 & 0.97 & 35.63 & 0.98 \\
\hline June.S3 & 3.15 & 3.45 & 0.97 & 29.07 & 0.98 \\
\hline July.S1 & 3.16 & 3.47 & 0.97 & 30.09 & 0.98 \\
\hline July.S2 & 3.68 & 3.58 & 0.97 & 32.97 & 0.97 \\
\hline July.S3 & 3.01 & 3.36 & 0.96 & 26.17 & 0.97 \\
\hline Aug.S1 & 3.29 & 3.52 & 0.97 & 31.74 & 0.98 \\
\hline Aug.S2 & 3.60 & 3.58 & 0.97 & 33.05 & 0.98 \\
\hline Aug.S3 & 3.10 & 3.44 & 0.97 & 29.40 & 0.98 \\
\hline Sep.S1 & 3.21 & 3.48 & 0.97 & 30.56 & 0.99 \\
\hline Sep.S2 & 3.34 & 3.54 & 0.97 & 33.39 & 0.99 \\
\hline Sep.S3 & 3.06 & 3.44 & 0.97 & 29.88 & 0.99 \\
\hline Oct.S1 & 3.26 & 3.52 & 0.97 & 33.11 & 1.00 \\
\hline Oct.S2 & 3.43 & 3.53 & 0.97 & 32.47 & 0.98 \\
\hline Oct.S3 & 2.44 & 3.17 & 0.96 & 22.85 & 0.99 \\
\hline Nov.S1 & 3.45 & 3.57 & 0.97 & 35.36 & 1.00 \\
\hline Nov.S2 & 1.99 & 3.00 & 0.95 & 20.00 & 1.00 \\
\hline Nov.S3 & 2.16 & 3.08 & 0.95 & 21.16 & 0.99 \\
\hline Dec.S1 & 2.64 & 3.30 & 0.96 & 27.00 & 1.00 \\
\hline Dec.S2 & 1.41 & 2.64 & 0.93 & 14.00 & 1.00 \\
\hline Dec.S3 & 1.30 & 2.54 & 0.92 & 12.25 & 0.99 \\
\hline Jan.S1 & 2.53 & 3.24 & 0.96 & 25.14 & 1.00 \\
\hline Jan.S2 & 1.49 & 2.67 & 0.93 & 13.76 & 0.99 \\
\hline Jan.S3 & 1.97 & 2.97 & 0.95 & 18.62 & 0.99 \\
\hline Feb.S1 & 3.49 & 3.56 & 0.97 & 32.81 & 0.99 \\
\hline Feb.S2 & 2.64 & 3.12 & 0.94 & 16.35 & 0.94 \\
\hline Feb.S3 & 2.71 & 3.28 & 0.96 & 25.62 & 0.99 \\
\hline Mar.S1 & 3.62 & 3.60 & 0.97 & 33.78 & 0.98 \\
\hline Mar.S2 & 3.66 & 3.62 & 0.97 & 35.53 & 0.99 \\
\hline Mar.S3 & 2.78 & 3.33 & 0.96 & 26.56 & 0.99 \\
\hline Apr.S1 & 3.83 & 3.68 & 0.97 & 37.69 & 0.98 \\
\hline Apr.S2 & 3.81 & 3.66 & 0.97 & 36.63 & 0.99 \\
\hline Apr.S3 & 3.56 & 3.59 & 0.97 & 34.13 & 0.99 \\
\hline May.S1 & 3.59 & 3.59 & 0.97 & 33.84 & 0.97 \\
\hline May.S2 & 3.70 & 3.61 & 0.97 & 34.04 & 0.98 \\
\hline May.S3 & 3.87 & 3.65 & 0.97 & 35.08 & 0.98 \\
\hline
\end{tabular}

A, Shannon's Diversity; B, Simpson's Diversity; C, Inverse Simpson's Diversity; D, Pielou's Evenness.
The values of diversity, richness and evenness indices of zooplankton in the Chashma Lake are presented seasonally and spatially (Table III). It was found that the Margalef value ranged from 1.30 to 3.87 , lowest in December at S3 and highest in May at S3. The Shannon's Diversity ranged from 2.54 (in December at S3) to 3.68 (in April at S1), whereas, the Simpson's Diversity value varied from 0.92 (in December at S3) to 0.97 (in April at $\mathrm{S} 1$ ) and the Simpson's Reciprocal Index ranged from 12.25 to 37.69 in December at S3 and in April at S1, respectively. The Pielou's Evenness value ranged from 0.94 in February at S2 to 1.0 in November at S2, and in December at S1 and S2 (Table III).
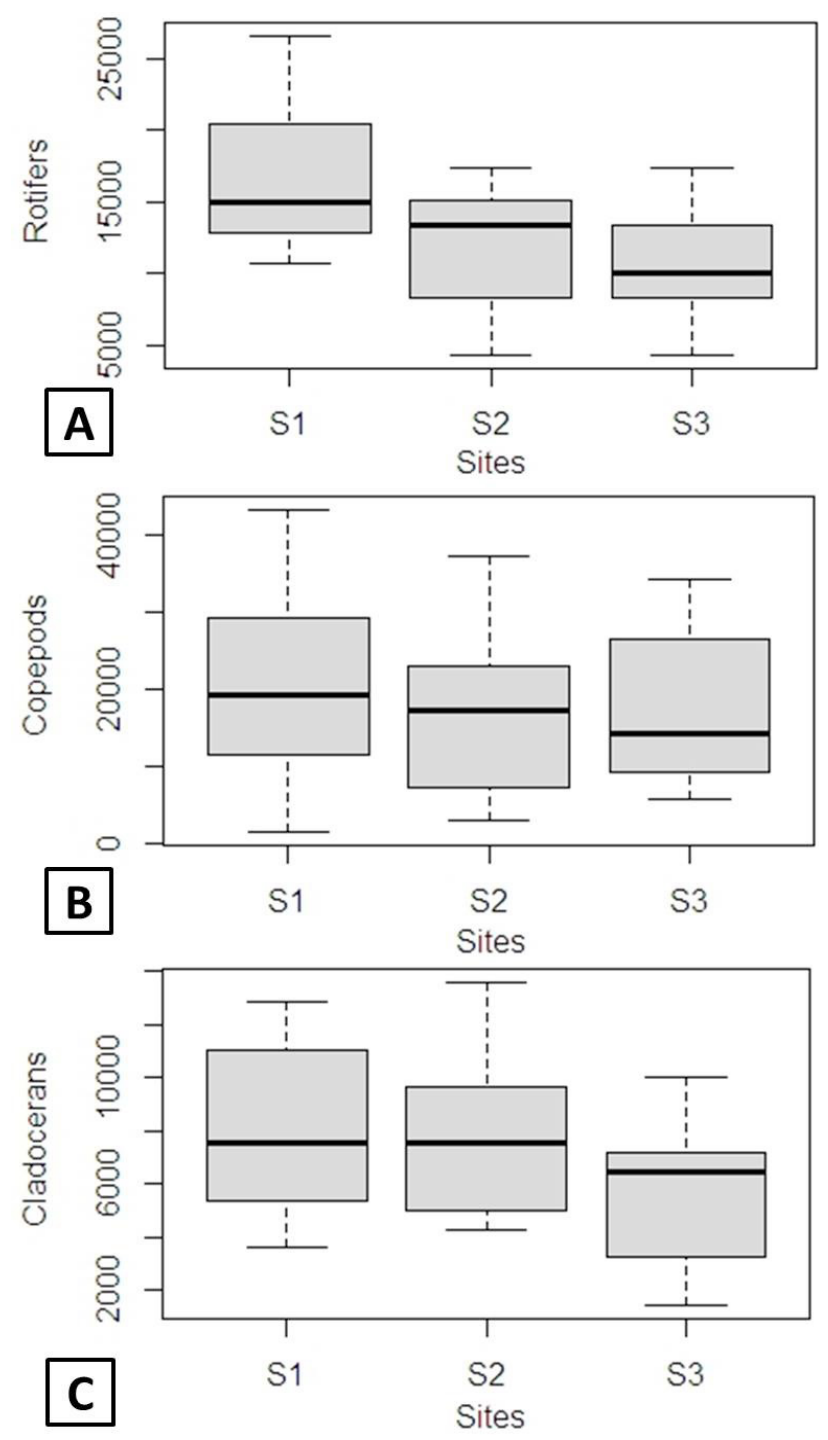

Fig. 2. Spatial comparison of zooplankton abundance through Box-plot: A, Rotifers; B, Copepods; C, Cladocerans at Chashma Lake. 
These values reveal that the species diversity, richness and proportion were high in April at S1 and low in December at S3. However, interestingly, the evenness value demonstrates that the species were less evenly distributed in February and November at S2 and the species frequencies were remained similar in December at S1 and S2. When this difference was examined spatially by Boxplot (Fig. 2), no significant difference was found between all the sites for copepods and cladocerans (ANOVA, $p$-value $>0.05$ ). Whereas, the significant difference for rotifers was found between $\mathrm{S} 1$ and $\mathrm{S} 3$ and between $\mathrm{S} 1$ and S2 (ANOVA, $p$-value $<0.05$ ); however, no significant difference found between S2 and S3 (ANOVA, $p$-value $>0.05$ ).

The abundance of zooplankton community in Chashma Lake was found throughout the year and almost at all stations, however, it was more prominent in summer months. Sulehria et al. (2009), Salve and Hiware (2010) and Devaraju (2015) have reported similar findings in their work. Altindag et al. (2007) observed dominance of rotifers in their study in Mogan Lake. In current study, for zooplankton species, Shannon's Diversity, Margalef value, Simpson's Diversity and Simpson's Reciprocal index values were also found. Shannon diversity is used to determine the diversity of a particular habitat and also for a comparison of various habitats for the abundance of the species (Clarke and Warwick, 2001). Evenness is a vital factor of diversity indices which presents the relation between the frequencies of species (Pielou, 1969) and it evaluates the relative abundance of different species which make richness of a habitat (Leinster and Cobbold, 2012). The Simpson index is used not only for counting the number of species, but also to find out the ratio of each species (Simpson, 1949). Simpson describes the possibility of any two individuals randomly caught belonging to different species (Bibi and Ali, 2013). Margalef index accounts for species richness of a habitat by the Gleason coefficient (Margalef, 1958). The index values rely on the number of species and not on the species frequencies.

In current study, the values for all measured indices were high in summer months and are in agreement with Maqbool et al. (2014). The values for diversity indices reveal that the zooplankton communities were heterogeneous by diversity index values especially when the difference between maximum and minimum values was high. During this study, it was also found that among three taxa of zooplankton, the copepods were dominant in occurrence from March to April, and were masked by rotifers in winter. Whereas, the cladocerans followed the same pattern as of copepods but were least abundant. Similar results have been reported by Mwaluma et al. (2003), Mahar et al. (2008), Maqbool et al. (2014) and
Sulehria et al. (2009).

Among rotifers, Asplancha priodonta was more prevailing in winter season, while other species like Lecane arcula, Polyarthra species, Euchlanis triquetra, Keratella tropica and Brachionus havanaensis were found abundant in summer. Similar findings have been reported by many researchers (Nogueira, 2001; Sampaio et al., 2002; Sulehria and Malik, 2012). Saddozai et al. (2015) found that Keratella spp. were dominant in April and July. Yağc1 (2014) also observed more Keratella from Lake Gölhisar, Turkey. It is also observed that Asplancha priodonta and Keratella valga were more prevalent at S3, while other species like Polyathra spp., Brachionus spp., Keratella tropica and Euchlanis triquetra were more abundant at S1. Among cladocerans, the Cerodaphnia cornuta, Daphnia and Alona were found more prominent in late winter and early spring at Chashma Lake. This may be due to low population of Cyanophyta in winter as compared to summer, which is not favored by Daphnia species, as reported by Kiss (2002). The Chydorus poppie and Cerodaphnia reticulate were found more prevailing in May and June whereas, Scapholeberis kingi and Macrothrix rosea were found abundant in May, June and July. This finding is in agreement with Mahar et al. (2008). Bosmina longirostris and Scapholeberis kingi showed their preference towards $\mathrm{S} 1$ and Cerodaphnia cornuta were higher at S3, while Alona guttata and Alona recticulata were more prevalent at $\mathrm{S} 2$. Whereas, all species of copepods were more abundant in summer as compared to winter. Furthermore, Macrocyclops fuscus, Diacyclops bicuspidatus and Eucyclops species were more prevalent at S1, whereas, Mesocyclop leukarti was more abundant at S3. Yildiz et al. (2007) and Ergonul et al. (2016) also observed the abundance of Keratella spp. and Bosmina longirostris in Anatolian lakes. The copepods found from Chashma Lake were abundant in summer and this finding is in agreement with Jhoshi (2011), Maqbool et al. (2014) and Devaraju (2015).

\section{CONCLUSION}

It is concluded that the Chashma Lake is very rich in zooplankton diversity in summer than in winter. The values of diversity indices reflect that zooplankton are more prevalent and rich in summer, whilst in terms of evenness, zooplankton community in the lake was found equitable.

\section{ACKNOWLEDGEMENTS}

We are greatly thankful to Fisheries Department, Government of Punjab, for providing logistic facilities 
for samples collection at Chashma Lake and to Pakistan Museum of Natural History, Islamabad, for laboratory facilities and identification of zooplankton species.

Statement of conflict of interest

The authors declare that there is no conflict of interests regarding the publication of this article.

\section{REFERENCES}

Akbar, M., Hassan, M.M.U., Nisa, Z.U., Hassan, M.M.U. and Hasan, M., 2009. Waterfowl diversity at Chashma Barrage (wildlife sanctuary, Mianwali) and Marala Headworks (Game reserve Sialkot) Pakistan during 1996-2005. Int. J. Agric. Biol., 11: 188-192.

Altindağ, A., Yiğit, S. and Ergönül, M.B., 2007. The zooplankton community of Lake Mogan. J. Freshw. Ecol., 22: 709-711. https://doi.org/10.1080/027050 60.2007 .9664832

Baloch, W.A., 2000. Occurrence of plankton communities in River Indus at Kotri Barrage, Sindh, Pakistan. Proc. Pakistan Congr. Zool., 20: 77-83.

Baloch, W.A., Jafri, S.I.H. and Soomro, A.N., 2005. Spring zooplankton composition of Rawal Lake, Islamabad. Sindh Univ. Res. J. (Sci. Ser.), 37: 4136.

Baloch, W.A. and Soomro, A.N., 2004. Rotifers of the adjacent areas of Hyderabad, Sindh. Pakistan J. Zool., 36: 319-322.

Baloch, W.A., Soomro, A.N. and Jafri, S.I.H., 2004. Zooplankton of highly saline water, near Hyderabad. Sindh Univ. Res. J. (Sci. Ser.), 36: 25-28.

Battish, S.K., 1992. Freshwater zooplankton of India. Mohan Primlani, Oxford \& ISHP Publishing Co., 66 Janapath, New Delhi.

Bibi, F. and Ali, Z., 2013. Measurement of diversity indices of avian communities at Taunsa Barrage wildlife sanctuary, Pakistan. J. Anim. Pl. Sci., 23: 469-479.

Clarke, K. R. and Warwick, R.M., 2001. Changes in marine communities: An approach to statistical analysis and interpretation, $2^{\text {nd }}$ edition. Plymouth, Primere, pp. 172.

Datta, T., 2001. Zoopalnkton diversity and physicochemical conditions of two wetlands of Jalpaiguri District, India. Int. J. appl. Biol. Pharma. Tech., 2: 576-583.

Devaraju, T.M., 2015. Studies on impact of physicochemical factors on the seasonal distribution of zooplankton in major lakes of Mandya District, Karnatalka. Int. J. environ. Biol., 5: 11-14.
Ergönül, M.B., Erdoğan, S., Altindağ, A. and Atasağun, S., 2016. Rotifera and Cladocera fauna of several lakes from Central Anatolia, Marmara and Western Black Sea region of Turkey. Turk. J. Zool., 40: 141146. https://doi.org/10.3906/zoo-1503-22

Hwang, J.S., Kumar, R. and Kuo, C.S., 2009. Impact of predation by the copepod, Mesocyclops pehpeiensis, on life table demography and population dynamics of four cladoceran species: A comparative laboratory study. Zool. Stud., 48: 738752.

Joshi, P.S., 2011. Studies on zooplanktons of Rajura Lake of Buldhana district, Maharashtra India. Sci. Res. Report., 1: 132-137.

Kazmi, Q.B., 2004. Copepods from shore and offshore waters of Pakistan. J. Mar. Sci. Tech., 12: 223-238.

Kiss, A., 2002. Distribution of microcrustacea in different habitats of a shallow lake in the FertoHansang, National Park, Hungary. Opusc. Zool. Budapest, 34: 43-50.

Leinster, T. and Cobbold, C.A., 2012. Measuring diversity: The importance of species similarity. Ecology, 93: 477-489. https://doi.org/10.1890/102402.1

Mahar, M.A., Baloch, W.A. and Jafri, S.I.H., 2000. Diversity and seasonal occurrence of planktonic rotifers in Manchar Lake, Sindh, Pakistan. Pakistan J. Fish., l: 25-32.

Mahar, M.A., Jafri, S.I.H. and Baloch, W.A., 2008. Seasonal variation and species composition of crustacean zooplankton (Order: Cladocera) in Manchhar Lake, Sindh, Pakistan. Pakistan J. Zool., 40: 65-68.

Maqbool, A., Sulehria, A.Q.K., Ejaz, M. and Hussain, A., 2014. Density, diversity and abundance of copepods in a pond. Biologia (Pakistan), 60: 57-62.

Margalef, R., 1958. Information theory in ecology. Gen. Syst., 3: 36-71.

Mizuno, T. and Takahashi, E., 1991. An illustrated guide to freshwater zooplankton in Japan. Tokai University Press, pp. 532.

Mwaluma, J., Osore, M., Kamau, J. and Wawiye, P., 2003. Composition, abundance and seasonality of zooplankton in Mida Creek, Kenya. Western Indian Ocean J. mar. Sci., 2: 147-155.

Naz, F., Qureshi, N.A. and Sehar, N.U., 2012. Temporal and spatial variations in the species composition, distribution and abundance of copepods in mangrove creek area along the Karachi coast, Pakistan. Indian J. mar. Sci., 41: 61-69.

Nogueira, M.G., 2001. Zooplankton composition, dominance and abundance as indicators of 
environmental compartmentalization in Jurumirim Reservoir (Paranapanema River), Sao Paulo, Brazil. Hydrobiologia, 455: 1-18. https://doi. org/10.1023/A:1011946708757

Park, K.S. and Shin, H.W., 2007. Studies on phyto and zooplankton composition and its relation to fish productivity in a west coast fish pond ecosystem. $J$. environ. Biol., 28: 415-422.

Pielou, E.C., 1969. An introduction to mathematical ecology. Wiley, NewYork.

Pennak, R.W., 1978. Freshwater invertebrates of the United State, $2^{\text {nd }}$ Ed. John Wiley and Sons, New York, pp. 803.

Saddozai, S., Achakzai, W.M., Masood, Z., Kakar, A., Somroo, A.N. and Baloch, W.A., 2015. An investigation on some new records of rotifer species occurs in Manchar Lake of province Sindh, Pakistan. Biol. Forum. Int. J., 7: 768-772.

Saler, S., 2009. Rotifers of Kepektas dam lake (ElazigTurkey). Iran. J. Sci. Technol. Trans., 33: 121-126.

Salve, B. and Hiware, C., 2010. Zooplankton diversity of Wan reservoir, Nagapur (MS) India. Trends Res. Sci. Tech., 2: 39-48.

Sampaio, E.V., Rocha, O., Tundisi, T.M. and Tundisi, J.G., 2001. Composition and abundance of zooplankton in the limnotic zone of seven reservoirs of the Paranapanema river, Brazil. Brazil. J. Biol., 62: 525-545.

Shah, J.A., Pandit, A.K. and Shah, G.M., 2013. Distribution, diversity and abundance of copepod zooplankton of Wular Lake, Kashmir Himalaya. J. Ecol. Nat. Environ., 5: 24-29. https://doi. org/10.5897/JENE12.100
Shelly, S.Y., Mirza, Z.B. and Bashir, S., 2011. Comparative ecological study of aquatic macroinvertebrates of Mangla Dam and Chashma Barrage wetland areas. J. Anim. Pl. Sci., 21(Suppl-2): 340350.

Simpson, E.H., 1949. Measurement of diversity. Nature, 163: 688. https://doi.org/10.1038/163688a0

Sulehria, A.Q.K. and Malik, M.A., 2012. Population dynamics of planktonic rotifers in Balloki Headworks. Pakistan J. Zool., 44: 663-669.

Sulehria, A.Q.K., Qamar, M.F., Anjum, R.F., Ejaz, M. and Hussain, A., 2009. Seasonal fluctuations of rotifers in a fish pond at district Bahawalnagar, Pakistan. Biologia (Pakistan), 55: 21-28.

Thor, P., Nielson, T.G., Tiselius, P., Pederson, T.J., Michel, C., Møller, E. F., Dahl, K., Selander, E. and Gooding, S., 2005. Post-spring bloom community structure of pelagic copepods in the Disko Bay, Western Greenland. J. Plankt. Res., 27: 341-356. https://doi.org/10.1093/plankt/fbi010

Yildiz, S., Altindağ, A. and Ergönül, M.B., 2007. The seasonal fluctuations in the zooplankton community of Eutrophic Lake; Lake Marmara (Manisa, Turkey). Turk. J., Zool., 31: 121-126.

Ward, H.B. and Whipple, G.C., 1959. Fresh water biology, $2^{\text {nd }}$ Ed. John Wiley and Sons, New York, pp. 1248.

Yağc1, M.A., 2014. Seasonal variations in zooplankton species of lake Gölhisar, a shallow lake in Burdur, Turkey. Pakistan J. Zool., 46: 927-932.

Yunfang, H.M.S., 1995. Atlas of fresh-water biota in China. Yauton University, Fishery College, China Ocean Press, Beijing, pp. 375. 